Mounah Abdel-Samad*

\title{
Legislators' Need for Civil Society Expertise: Tunisian Civil Society Legislative Advocacy Opportunity
}

https://doi.org/10.1515/npf-2016-0027

Abstract: The primacy of the Tunisian revolution and the country's successful democratic transition (Stepan 2012, “Tunisia's Transition and the Twin Tolerations." Journal of Democracy 23:89-103) make Tunisia an exemplar for analyzing legislators' demand for advocacy by civil society organizations or CSOs. Several researchers (Cavatorta 2012, “Arab Spring: The Awakening of Civil Society. A General Overview.” http://www.iemed.org/observatori-es/ arees-danalisi/arxius-adjunts/anuari/med.2012/Cavatorta_en.pdf, Benoit 2011, "The Counter-Power of Civil Society and the Emergence of a New Political Imaginary in the Arab World." Constellations: an International Journal of Critical and Democratic Theory 18:271-283. doi:10.1111/j.1467-8675.2011.00650. x, Kubba 2000, “Arabs and Democracy: The Awakening of Civil Society." Journal of Democracy 11:84-90) have explored the role of Tunisian civil society in the democratic transition; however, no study examined legislators' demand for CSOs' legislative advocacy in Tunisia. By exploring factors influencing legislators and their demand and need for legislative advocacy, this study sheds light on the inner works of policy makers and ways to influence them. This study finds that, contrary to the idea that governments in developing countries do not want civil society participation in politics, Tunisian legislators are open to and eager for legislative advocacy. Based on 40 survey conducted face to face with Tunisian legislators in the National Constituent Assembly, and archival analysis of the National Constituents Assembly sessions' minutes from 2011 until 2014, this study finds that Tunisian legislators have a high level of trust in CSOs, want their expertise, and are influenced by them when voting in parliament. These results have several potential impacts on understanding of the relationship between CSOs and government and more specifically legislature.

Keywords: Tunisia, civil society, legislature, advocacy

*Corresponding author: Mounah Abdel-Samad, San Diego State University, 5500 Campanile Drive, San Diego, CA 92182, USA, E-mail: msamad@mail.sdsu.edu 


\section{Introduction}

In 2011, Tunisians took the streets to demand democratic reform. They succeeded in toppling the government and ensuring a successful democratic transition (Stepan 2012), and inspired similar movements in Egypt, Libya, Morocco, Syria, and other Arab countries. Tunisian legislators wrote a new national constitution that was influenced by civil society's preferences.

Several researchers (Cavatorta 2012; Benoit 2011; Kubba 2000) have explored the role of Tunisian civil society in the democratic transition. However, to date no study has examined legislators' demand for legislative advocacy by civil society organizations (CSOs) in Tunisia. The literature on the relationship between CSOs and the state has examined the contentious nature of that relationship in different settings. ${ }^{1}$ A new question has emerged, namely why some Tunisian legislators accept or even to seek out CSOs legislative advocacy and why they trust CSOs. This paper argues that factors such as institutional capacity, legislators' responsiveness, legislators' professional background, and societal trust can explain Tunisian legislators' behavior regarding the role of CSOs in advocacy.

This study analyzed 40 surveys administered face-to-face with Tunisian legislators in the National Constituent Assembly. In addition, the archives of the National Constituent Assembly sessional minutes from 2011 to 2014 were analyzed. The results showed that, contrary to the idea that governments in developing countries do not want civil society to participate in politics, Tunisian legislators are highly receptive to legislative advocacy. Tunisian legislators in general have a high level of trust in CSOs. They appreciate the expertise that CSOs can provide. Legislators who respond to constituents through policy are the most interested in CSOs and their advocacy.

1 Young (1999) presents three models of the relationship between CSOs and the state: complementary, supplementary and adversarial. Other scholars, such as Reid (2000), contend that in the case of developing countries the relationship is on the adversarial side. Najam (2000) reexamines the relationship between CSOs and governments, by asserting that the division between developed and developing countries and between authoritarian and democratic regimes are not enough; there is a need to examine these relationships from a "strategic institutional interest of both government and CSOs" (Najam 2000, 376) perspective. Institutions in this case such as legislature are key to understanding the relationship between CSOs and the government. 


\section{Literature Review}

The literature on civil society in the Middle East and North Africa mainly discusses the role that civil society plays in the democratization process (Carapico 2003; Cavatorta 2012, 2006; Benoit 2011; Herrold 2016; Khrouz 2008; Kubba 2000; Langohr 2004; Yom 2005). Few researchers have examined CSOs legislative advocacy in developing countries (Abdel-Samad 2015; Guo and Zhang 2014). Those that have done so have examined the efforts of CSOs in legislative advocacy - rather than legislators' perceptions about CSOs' legislative advocacy, or the demands of legislators for CSO involvement. To the author's knowledge, no studies have examined legislators' perceptions of the advocacy efforts by CSOs in this region. By examining such perceptions, this paper adds new understanding to factors that affect the nature of the relationship between legislators and CSOs.

\section{Adversarial Relationship}

As mentioned above, a potential reason for the lack of studies on the connection between legislators and CSO legislative advocacy is the contentious relationship between governments and CSOs in non-democratic countries. Scholars have examined the government-CSO relationship from various perspectives (Appe and Layton 2016; Young 1999, 2000).

The adversarial perspective has been the focus of many studies (Appe and Layton 2016; Brinkerhoff and Brinkerhoff 2002; Najam 2000; Salamon 2002; Young 2000). CSOs in developed countries have a long history of informing and influencing policy (Boris 1999), often through legislative advocacy (Reid 1999). Yet, while many western CSOs have a high degree of credibility and provide well-supported information to lawmakers (Reid 1999), in other parts of the world the relationship between CSOs and lawmakers is strained (Clark 1991). Governments in authoritarian ${ }^{2}$ countries are often characterized as being distrustful of CSOs. Authoritarian regimes may restrict the rights of CSOs even to assemble (Salamon 1999) and may be suspicious of organizations that are inclined toward advocacy and reform (Smillie 1999). Social theorists such as Foucault, Gramsci, Habermas, and Marx often characterized civil society as opposing the state (Pollard and Court 2005), and more recent scholars have

2 Distrust of CSOs is not limited to authoritarian countries but can occur in semi-authoritarian or transitioning democracies too. The relationship between CSOs and the state could vary depending on where the country is on the continuum from authoritarian to democratic. 
extended this idea by assuming that civil society is necessarily in conflict with the state. This strained relationship indicates that the state and its political players do not trust CSOs and perceive them as competitors. Rojas (1999) asserted that CSOs' opposition to the state compels those organizations to represent specific political values. Similarly, Anheier, Glasius, and Kaldor (2001) pointed out that the strength of civil society is rooted in its ability to hold those in power accountable.

The adversarial relationship between CSOs and the government or state has been changing in countries such as India, Peru, Columbia, and Mexico (DiazAlbertini 1993; Kumar 1997; Appe and Layton 2016). An important question is how to stimulate research on individual governments, to understand institutional decisions regarding what relationship a government desires with CSOs.

\section{CSO Advocacy}

The literature on civil society advocacy has grown steadily (Berry 2001; Dalrymple 2004; Ezell 2006; Hudson 2002; Boris 1999; Boris and Steuerle 2006; Schmid, Bar, and Nirel 2008). However, most of this research has focused on Western democracies and on the role and efforts of CSOs (Appe and Layton 2016; Guo and Zhang 2014; Najam 2000; Smith 1984). Studies of legislative advocacy (Saidel 2002; Schmid, Bar, and Nirel 2008; Mosley 2010; Child and Grønbjerg 2007) have examined CSOs' organizational capacities and legal restrictions, and the impact of those factors on CSOs' legislative advocacy efforts, mainly in developed countries.

The definition of advocacy has evolved over time (Almog-Bar and Schmid 2013; Reid 2000; Ezell 2006; McCarthy and Castelli 2002; Hopkins 1992; Avner 2002). Earlier definitions focused on working for a cause, whereas more recent definitions highlight contributing to a collective action, idea, or policy. Advocacy can also be divided into subcategories, ranging from case advocacy to general advocacy, from direct to indirect, from pragmatic to legislative, and from case to policy advocacy (Almog-Bar and Schmid 2013; Andrews and Edwards 2004; Kimberlin 2010; Laws 1997; Mosley 2010). Reid (cited in Saidel 2002) provided a typology of action advocacy that included legislative advocacy. According to McCarthy and Castelli (2002), legislative advocacy occurs when CSOs directly or indirectly engage legislative entities to affect policy outcomes. CSOs engage with legislators and legislative staff to highlight their viewpoints and shape policies.

Legislative advocacy can occur at different stages (Ezell 2006). CSOs may advocate for their policy preferences during either the legislative session, 
political campaigns, or non-sessions. During legislative sessions, CSOs can conduct one-on-one lobbying, testify in committees for legislators, produce research papers (position papers), alert constituents, provide expert testimonies, and work with legislative staff (Avner 2002; Abdel-Samad 2015; Ezell 2006). The provision of expertise through these avenues informs legislators of the impact a proposed policy might have on constituents, and allows legislators to respond to constituents by including their needs in the political agenda.

\section{Theory and Hypotheses}

To understand the behavior of legislators and their desire for advocacy by CSOs, this paper examines several aspects of legislators' responses. These include the responsiveness tool that legislators use, and the institutional capacity that is provided to individual legislators.

\section{Legislative Representation}

Pitkin (1967) and Miller and Stokes (1963) examined the delegate and trustee roles of legislators (Jewel 1983), and highlighted how responding to constituents is an essential factor in democratic representation. Using the rational choice model, ${ }^{3}$ Mayhew (1974) and Kingdon (1989) explained that legislators respond to constituents partly to ensure they are reelected. Eulau and Karps (1977) outlined four categories of legislators' responses to constituents, namely allocation, policy, services, and symbolic responsiveness. Allocation involves legislators engaging in casework (personal individual demand) to satisfy the needs of specific constituents. Policy responsiveness occurs when legislators respond to constituents by voting on policies (Miller and Stocks 1963). Service responsiveness is reflected in legislators' efforts regarding the distribution of pork-barrel projects in their districts. Finally, symbolic representation occurs when legislators take a public stand on issues that constituents care about (Fenno 1978).

Researchers who study legislative institutions and the impact of advocacy on legislators' votes have generally focused on developed countries, specifically the United States (Wright 1990; Smith 1984). They found that advocacy efforts

3 While rational choice explains some legislators' behavior, there are other complementing and competing models that explain legislators' behavior. (NEED Citation). 
and lobbying can influence legislators' votes. Hence, advocacy efforts may affect the policy outcome as well as affecting citizens directly. Because policies have a direct impact on the lives of constituents, legislators try to understand the consequences of their policy vote (Smith 1984). They examine who will be affected and how - and to what extent, as well as the likely reaction to the new policy (Smith 1984). Legislators try to invest their time, resources, and datagathering efforts to reflect on the effects of a policy before voting.

Legislators who respond to constituents mainly through casework and porkbarrel are less likely respond through policy because they lack both financial and human resources. They can ill afford the time that would allow them a better understanding of the impact of their vote (Abdel-Samad 2009). By contrast, legislators who respond through policy need data and analyses related to the topic of the vote (Smith 1984). To secure such information, legislators must invest time to access organizations or experts who can provide them with such data. They rely on fellow legislators, bureaucrats, political parties, media, personal and institutional staff, and the expertise of CSOs. Such information sources enable legislators to better assess the impact of a proposed policy. CSOs are therefore an important ally because they provide expert opinions and they possess an intimate understanding of the needs and demands of constituents. Hence, legislators who respond to constituents through policy often desire information from CSO sources to a larger degree than legislators who respond through casework and the pork-barrel approach.

For legislators to participate and be effective in the policy-making process they need institutional resources, both human and financial, to assist in the process and enable them to respond to constituents. Resource mobilization theory suggests that to influence policy making, an organization must possess the human and financial capacities that allow it to do so (Bass et al. 2007; Saidel 2002). Human capacity can take the form of qualified staff who can assist in data collection and analysis or reduce the casework demand on legislators. One way of accessing data to understand the impact of policies is to secure resources such as personnel. Legislators seek research capacities and expert analysis to help them understand their constituents' needs in policy decisions (Fenno 1978). Such analysis can be provided by qualified personal and institutional staff (Sabatier and Whiteman 1985). Rosenthal (1996) found a link between the number of personnel and the degree of professionalism in legislatures. The number of staff has also been shown to shape the policymaking process (Romzek and Utter 1997; Neal 1996) ${ }^{4}$ and to improve oversight

4 For a comprehensive summary of the role of staff in policy making, please refer to Susan Webb Hammond (1996) "Recent Research on Legislative Staff." 
(Aberbach 1990; Jewell and Whicker 1994). Staffers help legislators to maintain contact with their constituents and assist in addressing the constituents' casework needs and other demands (Squire 1993; Richardson and Freeman 1995; Rosenthal 1986). By taking over casework and other administrative tasks, staff allow legislators more time to invest in policy making. In addition to staff, legislators can seek data and analysis from other sources, including CSOs.

The availability of financial resources may enable legislators to hire more staff or to contract out data collection and policy analysis. Legislators in the Middle East and North Africa (Suleiman and Henderson 2007) often lack institutional and personal policy-making resources, thus increasing legislators' dependence on other sources of information and expertise - such as CSOs. This dependence (Pfeffer and Salancik 1978) on CSOs for information gives the CSO some influence over legislators and the policy-making process. Legislative studies in the Middle East and North Africa (Abdel-Samad 2009; Benstead 2008) have shown that many legislators spend most of their time responding through casework (allocation) and pork-barrel (services) rather than policy responsiveness.

Finally, trust is a necessary precursor to legislators' receptiveness of CSOs legislative advocacy efforts. If legislators trust the entity that provides the analysis (Bourdeaux 2008; Raudla 2012), and if the information benefits the odds of their reelection and fuels their desire to play an active role in the policy-making process, those legislators will be more open to legislative advocacy. In such cases they are likely to be influenced by CSO opinions. By contrast, if a government has an adversarial relationship with CSOs (Appe and Layton 2016; Brinkerhoff and Brinkerhoff 2002; Young 2000; Salamon 1999), and policy makers do not trust CSOs, legislators will not seek expert opinions or information from the CSOs. In Tunisia, for example, the historically strained relationship between the state and CSOs is changing under the new democratic regime.

\section{Hypotheses}

To answer why the relationship between CSO and governmnet in Tunisia is not adversarial and why trust exist between legislators and CSOs, this study proposes the following three hypotheses.

H1: Legislators involved in securing casework and pork-barrel for their constituents are less likely to be influenced by CSOs legislative advocacy 
H2: The lack of legislative staff renders legislators more welcoming of the legislative advocacy role played by CSOs.

H3: Contrary to studies that have reported that developing countries distrust civil society, Tunisian legislators trust CSOs.

\section{Democratic Change in Tunisia}

The Tunisian revolution of 2011 - also called the Jasmine revolution - induced a transition from the previous authoritarian regime to a new democracy. Although CSOs did not instigate the revolution, their members participated in the demonstrations (Benoit 2011) and the CSOs played an important role in the democratic transition process.

Under Ben Ali (the previous president of Tunisia who fled the country), the authoritarian regime had used the laws of association (Law 59-154) to keep CSOs under its control. The regime had selectively allowed certain CSOs to exist, especially those that focused mainly on economic development. Other organizations were actively assimilated by the regime to aid in its adaption and survival (Deane 2013; European Union 2012). CSOs focusing on human rights and union issues continued to exist, but paid a high political price (Deane 2013; Human Rights Watch 2005). Among those that survived was the General Union of Tunisian Workers, which played important roles in the union strikes in Gafsa in 2008 and Sfax in 2010. These two events arguably provided fuel for the 2011 uprising (Deane 2013). The UGIT supported workers' protests as they spearheaded demands for better working conditions and pay.

After the revolution, CSO members participated in the High Council for the Realization of the Objectives of the Revolution, Political Reform, and Democratic Transition (Deane 2013). This council provided oversight for the democratic transition. The General Union of Tunisian Workers, the Tunisian Confederation of Industry Trade and Handicrafts, the Tunisian Human Rights League, and the Tunisian Order of Lawyers jointly received the Nobel Peace Prize for the role they had played in ensuring the democratic transition continued successfully in Tunisia (BBC 2015). These organizations had convinced the ruling coalition to provide political concessions that led to a more stable government.

The National Constituent Assembly also rewarded the valuable role that CSOs played in the democratic process by accentuating the importance of CSOs in the new law of association. This new law (Association law number 88 of 2011) encouraged CSOs to play a bigger role in the political process, and it supported CSOs to engage in advocacy by providing them with certain rights. These rights included the right to publish reports, to access information, to 
evaluate public institutions, and to provide proposals to improve those institutions (Association Law number 88 2011). The law also protected CSOs by limiting the power of the state to stop or hinder their work, thereby granting legal protection for a more active role in the political process. In addition, the internal rules of parliament ${ }^{5}$ allow CSOs to engage in legislative advocacy and debate at various stages of the development and approval of a bill. Legislative advocacy can occur at the committee and general assembly stages (Association Law number 88 2011). Not only can CSOs lobby legislators individually, they can also lobby political parties to try to convince members to vote in a certain way regarding a proposed policy.

\section{Methodology}

Tunisia provides an excellent case study of a developing nation starting a democratic transition after a long history of authoritarian rule. Tunisians succeeded in toppling their authoritarian ruler and electing their legislative and executive branches in 2011. Tunisia's democratic transition has prevailed throughout two legislative elections, the election of two presidents, and voting for several prime ministers. Thus, Tunisia is a model of democratic transition from which other Arab countries can benefit.

This study collected data from 40 legislators. The survey was administered face-to-face with Tunisian legislators in May to July of 2013, in Arabic. The sample of legislators was obtained using a snowball technique, and represented $18.2 \%$ of the members of parliament. The sample also represented most of the parliamentary bloc (only the Democratic transition and the Democratic Alliance blocs were not represented in the sample). The sample was composed of $20 \%$ women and $80 \%$ men, thus slightly under-representing women - who constituted $30.14 \%$ of the National Constituent Assembly at the time (Table 1).

The survey questions focused on the following topics: factors that influenced legislators' votes, the role of CSOs in their votes, the number of personal and institutional staff allocated to legislators, time spent on casework, time spent on policy and pork-barrel, and characteristics of their constituents. The questions also examined the following issues: interactions between legislators

5 Not only did the NCA welcome CSOs, but the whole political system redistributed powers to the different political institutions. Hence, the parliament that played a "rubber stamp" role under Ben Ali currently plays a more active and influential role. Political powers are now divided among the presidency, prime minister and cabinet, parliament, and independent judiciary. 
Table 1: Sample composition.

\begin{tabular}{lrr}
\hline Legislators & Sample & Constituents assembly \\
\hline Female legislators & $8(20 \%)$ & $67(30.87 \%)$ \\
Male legislators & $32(80 \%)$ & $150(69.12 \%)$ \\
Nahda & $13(32.5 \%)$ & $87(40.09 \%)$ \\
No party affiliation & $14(35 \%)$ & $52(23.96 \%)$ \\
Congress for the Republic & $3(7.5 \%)$ & $14(6.45 \%)$ \\
Dignite & $1(2.5 \%)$ & $10(4.6 \%)$ \\
Bloc democratic & $7(17.5 \%)$ & $18(8.29 \%)$ \\
Ettakatol & $2(5 \%)$ & $12(5.52 \%)$ \\
\hline
\end{tabular}

Source: https://majles.marsad.tn/assemblee

and CSOs, legislators' perceptions of problems facing CSOs, legislators' trust in CSOs, CSOs' influence on legislators' votes, and the desire of legislators to obtain expert opinions from CSOs. The questions were a combination of closed-ended and open-ended questions. For closed-ended questions, the answers varied. Some used a Likert scale (a lot, moderate, a little, not a lot); some allowed for only a yes or no response; and others gave the interviewee several options or a multiple choice set (see Online Appendix for a list of the questions).

To measure legislators' perceptions of CSOs, the study asked legislators about the following aspects: how much influence CSOs had on their vote; to what extent the legislators trusted CSOs; whether they would like CSOs to provide them with data related to their area of expertise; and what obstacles hindered the CSOs from engaging in advocacy. To assess institutional support in the form of staff, the author asked questions about the number of personal assistants, parliamentary staff who helped with policy making, and how many political party staff members helped with policy making. The author also asked about the tasks performed by both personal assistants and institutional staff.

The author then assigned a number from 1 to 4 to represent the answers of the scaled questions, with 1 representing the least favorable choice (not a lot) and 4 representing the most favorable. For dichotomous responses, zero (0) was assigned for "no" and 1 for "yes" answers. The SPSS statistical program was used to explore relationships among the variables.

In addition to the in-person surveys, the author performed a content analysis of all the minutes from legislative sessions for 2011-2014 that were available online, in which the terms "civil society" or "civil associations" were mentioned. CSOs in this case represented all civil society institutions except the media, religious entities, and political parties. (The term "civil society organization" translates into Arabic as "Mouaassasat Al-Moujtamaa Al-Madani" - a term that 
tends to exclude media, political parties, and religious entities such as mosques or churches.) When legislators referenced CSOs, the results were coded into three categories: the CSO's role as part of the revolution, its role in policy making, and its role in ensuring the continuity of democratic traditions. For example, when legislators mentioned how CSOs paid dearly in the streets and as such deserve to be part of the policy process, the author coded that as role as being part of the revolution. In other cases, when legislators mentioned the need for CSOs to be part of the procedures that create policy, this was coded as policy making. Finally, when legislators mentioned CSOs and their work as part of building the democracy, the answers were coded as the continuity of democratic tradition.

A limitation of this paper is that the results are based mainly on legislators' opinions and perceptions. To minimize this limitation, the author promised confidentiality and built internal reliability measures into the question protocol to improve the likelihood of truthful responses.

\section{Findings}

This study found support for the three proposed hypotheses regarding Tunisia. First, legislators who were mainly responding to their constituents through casework and a pork-barrel approach did not want legislative advocacy. Second, in contrast to frequent characterizations of governments as being suspicious of or opposed to CSOs, this study demonstrated that legislators trust CSOs and are influenced by the opinions of CSO personnel. Finally, a lack of institutional or personal legislative staff evidently enhanced the desire among legislators for CSOs to play a role of legislative advocacy. Below is a detailed description of the survey and content analysis findings.

The study found that legislators who focused on casework and pork-barrel saw no electoral benefits in asking for data from CSOs. The analysis showed a negative correlation $\left(-0.328^{6}\right)$ between legislators spending most of their time securing goods for their district and the desire for information from CSOs. Similarly, a negative correlation $(-0.568)$ was noted between legislators' need to spend time responding to casework for their constituents and their desire for information from CSOs.

Legislators who used policy as a tool to respond to their constituents were investing their time and effort and seeking information from CSOs to understand

6 All correlations in this study are significant at the 0.05 level, 2 tailed. 
the impact of their votes. The analysis yielded a positive correlation $(+0.333)$ between time spent on policy making and the influence that CSOs had on legislators' decisions.

In addition, the analysis showed that Tunisian legislators overwhelmingly trusted CSOs, with $80 \%$ of the interviewees answering the question "How much do you trust CSOs?" with the responses of "a lot” or "moderately." Legislators trust in CSOs was also highlighted in the content of the National Constituents Assembly.

The records of the legislative sessions of the National Constituent Assembly show that legislators debated repeatedly on the important role of CSOs in representing society and the need for them to be a part of the political decision-making process. Some legislators went so far as to request that CSOs become official policy makers. One legislator commented that "the government, parliamentary blocks, and civil society should have the right to propose a bill." Others highlighted the need to include the Union of Tunisian Workers, thus stressing the important role that this union (among others) had played in the democratic transition.

In addition to the high level of trust in CSOs, $52.5 \%$ of surveyed legislators indicated that CSOs influence their decisions on how to vote in the National Constituent Assembly either to a moderate extent (45\%) or a lot (7.5\%).

The content analysis of the minutes of legislative sessions indicated that two main points of view were presented to justify the need for CSOs to be active participants and influencers in the political decision-making process. First, legislators noted that the success of Tunisian democracy is based on the inclusion of most of Tunisian society in the political process. Legislators view the participation of CSOs in the political process as a guarantee that the constitution and the new democratic system can succeed. One legislator stated that "Civil society has a role in insuring the checks and balances especially when it comes to the power of the executive branch." During their debates, legislators repeatedly stated that it is important to "include all the living powers including those who represent civil society." Legislators wanted CSOs to be included in the policy-making process related to the budget and other policies. One legislator went so far as to indicate that the participation of civil society in the policy-making process offers a means to fight extremism and to maintain the connection between political leaders and citizens. The legislator explained as follows: "[A] modern state depends a lot on civil society. Civil society can modernize all sectors ... Depending on civil society will shield us from extremism and limit the political gap between the rulers and the citizens." This sentiment was echoed in speeches by the President of the Republic, the Speaker of the House, and many other legislators who stressed the importance of including CSOs in the political process. 
Second, legislators advocated a role for CSOs in the political process because they perceived CSO personnel as experts in their fields. In discussing the role that CSOs can play in the state, several legislators insisted on recognizing the expertise of CSOs personnel. The chair of the committee on parliamentary rules, when debating the internal rules, outlined his belief in the importance of CSOs as a source of experts. He indicated repeatedly that internal rules allow the speaker to solicit expert help from CSOs (Legislative session 13, 2012).

This study found that linked to their trust in CSOs, Tunisian legislators are eager for legislative advocacy by CSOs. Most surveyed legislators (87.5\%) answered that they want more information related to CSOs' areas of expertise. Finding themselves lacking qualified staff at the institutional and personal level was a factor that pressed legislators to seek expertise from other entities, including CSOs (Table 2).

Table 2: Number of staff legislators have access to (Percentage).

\begin{tabular}{lrrrrr}
\hline & None & $\mathbf{1}$ & $\mathbf{2 - 4}$ & $\mathbf{5 - 1 0}$ & $>\mathbf{1 0}$ \\
\hline Personal & 87.5 & 10 & 2.5 & - & - \\
Institutional & 75 & 7.5 & 15 & 2.5 & - \\
Party & 50 & 20 & 22.5 & 5 & 2.5 \\
\hline
\end{tabular}

Contrary to developed parliaments, this study found that most surveyed Tunisian legislators do not have any personal staff $(87.5 \%)$ or institutional staff $(75 \%)$ to help with tasks. The situation is exacerbated by the lack of available financial resources that would allow legislators to hire personal staff to assist in policy making. The salary of a Tunisian legislator was about USD1,500 per month in 2012 (Marsad Tunisia 2012), which meant they could not easily hire a qualified personal research assistant. Legislators (12.5\%) who had personal staff usually had one person, who, according to legislators, mainly helped with policy research.

Legislators (25\%) who enjoyed the support of institutional staff indicated that these staffers mainly served the leadership in the Assembly. Not only do Tunisian legislators lack institutional and personal staff, they also lack research institutions under the control of the legislative branch. In the United States, the Congressional Budget Office, the Congressional Research Office, and the Government Accountability Office are available to help legislators with policy analysis. In addition to the lack of personal and institutional staff, half of legislators had no party staff to help them (Table 2). These factors rendered legislators quite dependent on other entities, such as CSOs, for expertise and policy analysis. 
The results of the study indicate a clear negative correlation $(-0.317)$ between lack of personal staff and the influence that CSOs have on legislators' voting. In addition, a positive correlation $(+0.319)$ was noted between CSO influence on voting and the number of institutional staff involved in administrative tasks.

Although there is institutional openness and legislative readiness for CSOs' legislative advocacy, a gap in trust and desire for legislative advocacy still exists between CSOs and legislators. Comparing the perceptions of legislators and those of CSO members about the obstacles facing CSOs, the study found that both groups articulated similar - and accurate - assessments of the organizational obstacles CSOs face. Legislators agreed with CSO personnel that the lack of qualified employees and lack of funding were key obstacles. However, a gap emerged between legislator and CSO perceptions regarding legislators' confidence in CSOs and responding to advocacy. Contrary to the results of the study conducted by the European Union of 57 Tunisian CSOs (European Union 2012) in which CSOs perceived that policy makers did not trust CSOs or vote according to CSOs' recommendations, legislators in this study trusted CSOs and were influenced by them in deciding how to vote (Table 3).

Table 3: A comparison of perceived obstacles.

\begin{tabular}{ll}
\hline CSOs & Legislators \\
\hline $\begin{array}{l}\text { Lack of qualified employees with expertise in } \\
\text { society activities }\end{array}$ & $40 \%$ believe CSO lack qualified employees \\
$\begin{array}{l}\text { Lack of funding and connection to sources of } \\
\text { funding }\end{array}$ & $47.5 \%$ perceive that CSO lack funding \\
$\begin{array}{l}\text { Lack of access to information and data } \\
\text { Lack of confidence between political actors and }\end{array}$ & NA 80 trust CSOs \\
$\begin{array}{l}\text { the CSOs } \\
\begin{array}{l}\text { Lack of political will on the part of policy makers } \\
\text { to take into consideration the reports and }\end{array}\end{array}$ & Legislators are influenced by CSO (52.5\%) \\
information generated by CSOs & $\begin{array}{l}12.8 \% \text { believe that CSO do not advocate } \\
\text { because they do not want to be perceived as } \\
\text { political }\end{array}$ \\
\hline
\end{tabular}

The results of this study indicate that more communication between CSOs and legislators can help legislative advocacy efforts, and would improve CSOs' influence in policy making. While the author acknowledges the need to overcome some of the organizational factors that affect the capacity of CSOs, an opportunity exists for these organizations to influence policy. 


\section{Analysis}

The relationship between legislators and CSOs in Tunisia has been less adversarial. This was the result of the responsiveness tool used, the high trust in CSOs by, and the lack of institutional and personal capacities on the part on the part of legislators.

Based on the assumption that legislators want to be reelected and advance their political careers (Mayhew 1974; Kingdon 1989), legislators evaluate the best way to respond to constituents and where to invest their energy and time. Legislators who respond to constituents mainly by casework and pork-barrel do so at the expense of participation in policy making or influence over the proposed policies (Abdel-Samad 2009). Legislators who respond through casework end up with many personal demands that monopolize their time and reduce their ability to engage in policy making. Hence the negative correlation between spending time on casework and legislators desire for data from CSOs. Given the lack of research capacity at the institutional and personal level, and the limited staff at the party level, legislators are unable to complete all their tasks or to respond properly to their constituents. Therefore, they focus on a specific tool of responsiveness (casework and pork-barrel) to maximize their chance of reelection.

To respond to constituents through policy, legislators need to understand the policy details and how these details impact their constituents. Hence, legislators need specialized information on the bills for which they are voting. There are various entities that can provide expert information that can help legislators with policy-making decisions, such as think tanks, bureaucrats, media, and CSOs. The knowledge that CSO personnel possess about their recipients' needs, and their expertise in the area in which they specialize, can assist legislators by providing them with a better understanding of the needs of constituents and of factors affecting services. Legislators who seek information from CSOs to respond through policy become influenced by those CSOs; hence, the positive correlation between responding through policy and CSOs' influence on legislators' vote.

While responsiveness tool affects legislators' openness and desire for CSOs legislative advocacy, trusting CSOs is an important prerequisite for a more constructive relationship between legislators and CSOs. Contrary to the perception that CSOs in developing countries undermine the power of the state (Salamon 1999; Pollard and Court 2005), Tunisian legislators see CSOs as trustworthy and value their specialized knowledge. Legislators' trust in CSOs is grounded in the political capital that CSOs built during and after the 2011 revolution, legislators' professional background, and societal trust of CSOs. 
The role that CSOs played in the uprising included being strong participants rather than instigators. Their subsequent role included advocating for more democratic rights, and mediating to alleviate an existential political deadlock between political parties. Their participation in the High Council for the Realization of the Objectives of the Revolution, Political Reform, and Democratic Transition was also noteworthy. All these roles allowed CSOs to build strong political capital within Tunisian society and among legislators specifically, hence increasing legislators' trust of them.

In addition, many (46\%) newly elected legislators were at some point a member of a CSO themselves. Being part of these institutions might result in greater respect or trust and the view that CSOs' work is important and in the interests of the country. As for societal trust of CSOs, according to the Arab Barometer results from surveys conducted between 2012 and 2014, 53\% of the surveyed Tunisian citizens answered that they trusted CSOs a limited amount, medium amount, and a lot. Legislators are members of society, respect society's perceptions, and would like to keep their constituents happy; hence, societal trust in CSOs has a direct impact on their trust in CSOs.

Finally, the lack of personal and institutional staff increases legislators' dependence on CSOs for information about their areas of expertise especially if legislators are using policy to respond to constituents. A lack of personal staff also reduces the time and knowledge available to legislators to engage in policy making. Personal staff could provide policy research to improve legislators' knowledge about the issue at hand, or they could attend to other tasks to free the legislator's time for studying the policy. Hence the negative relationship between the number of personal staff and CSOs' influence on legislators' vote on the one hand and the positive relationship between institutional staff administrative tasks and CSOs influence on legislators' vote.

\section{Conclusion}

Most studies examining CSOs' legislative advocacy efforts have focused on CSOs' side by examining organizational and legal factors that affect CSOs' engagement in legislative advocacy. The present study complements this literature by examining the demand side for legislative advocacy. In contrast to theories that pit CSOs against the state in developing countries, legislators in Tunisia welcome legislative advocacy. Legislators trust CSOs and want their expert input, and they are influenced by CSOs when deciding how to vote. 
The Tunisian democratic transition and the trust that society and legislators extend to CSOs give CSOs an advantage in influencing policies. The performance of CSOs during and after the 2011 revolution, their representation of activists who led the revolution, and the background of a large minority of legislators who were previously members of CSOs are factors that contribute to the high level of trust in CSOs. In addition, CSOs have occupied an important place in the political arena through the passage of legal protections and the high value that legislators place on their expertise and participation in the policy process. The new legal protections constitute an important foundation for the relationship between the state and CSOs (Uphoff and Krishna 2004; Young 2010). A relationship that is built on trust and inclusion benefits the state by improving the representation of diverse constituencies, and by holding legislators accountable.

Legislators wanting reelection and career advancement not only trust CSOs but also seek their expertise. This combination of trust and need provides CSOs with influence over legislators' votes in the National Constituent Assembly. However, CSOs' influence in legislative advocacy is limited to legislators who respond to constituents mainly by policy. Legislators' decisions on how to invest their time in responding to constituents guides their focus on either policy responsiveness or on casework and pork-barrel approaches. Focusing on policy is time consuming and requires adequate research capacity. If legislators lack personal and institutional legislative staff, their dependence on the expertise of CSOs increases. This scenario improves the potential success of CSOs' legislative advocacy.

While legislators trust CSOs and want their expertise, a divergence of perceptions on the importance of legislative advocacy persists between legislators and CSOs. Legislators seem to desire more legislative advocacy at a time when CSOs do not think their opinion is needed. CSOs have opportunities to voice their ideas because of legislators' need for expert opinion, the openness of the legislative institution, and the trust that CSOs enjoy.

Although CSOs in Tunisia already enjoy some opportunity to influence legislators' votes, Tunisian CSOs face similar obstacles to engaging in legislative advocacy that CSOs in other developing countries face (Andrews and Edwards 2004; Schmid, Bar, and Nirel 2008; Mosley 2010). Tunisia's historical and organizational factors, such as financial and human resources, accessibility, and time all affect the ability of CSOs to engage in advocacy.

\section{References}

Abdel-Samad, M. 2009. “Exchanging Favours: The Predominance of Casework in Legislators' Behaviour in Jordan and Lebanon." Journal of Legislative Studies 15:420-438. 
Abdel-Samad, M. 2015. "Legislative Advocacy under Competitive Authoritarian Regimes: The Case of Civil Society in Jordan." Voluntas: International Journal of Voluntary and Nonprofit Organizations. First published online on 29 May 2015. doi:10.1007/s11266-015-9592-0.

Aberbach, J. 1990. Keeping a Watchful Eye: The Politics of Congressional Oversight. Washington DC: The Brooking Institute.

Almog-Bar, M., and H. Schmid. 2013. "Advocacy Activities of Nonprofit Human Service Organizations: A Critical Review." Nonprofit and Voluntary Sector Quarterly 43:11-35.

Andrews, K. T., and B. Edwards. 2004. "Advocacy Organizations in the U.S. Political Process." Annual Review of Sociology 30:479-506.

Anheier, H., M. Glasius, and M. Kaldor, eds. 2001. Global Civil Society. Oxford: Oxford University Press.

Appe, S. M., and M. D. Layton. 2016. "Government and the Nonprofit Sector in Latin America." Nonprofit Policy Forum 7:117-135.

Association Law number 88, 2011. Accessed May 15, 2016. http://www.icnl.org/knowledge/ library/index.php.

Avner, M. 2002. The Lobbying and Advocacy Handbook for Nonprofit Organizations: Shaping Public Policy at the State and Local Level. St Paul, MN: Amherst H. Wilder Foundation.

Bass, G., D. Arons, K. Guinane, and M. Carter. 2007. Seen but Not Heard: Strengthening Nonprofit Advocacy. Washington: The Aspen Institute.

BBC. 2015. Nobel Peace Prize for Tunisian National Dialogue Quartet. Accessed June 5, 2016. http://www.bbc.com/news/world-europe-34485865.

Benoit, C. 2011. "The Counter-Power of Civil Society and the Emergence of a New Political Imaginary in the Arab World." Constellations: an International Journal of Critical and Democratic Theory 18:271-283. doi:10.1111/j.1467-8675.2011.00650.x.

Benstead, L. 2008. Does casework build support for a strong parliament? Legislative representation and public opinion in Morocco and Algeria. PhD Diss., The University of Michigan.

Berry, J. M. 2001. "Effective Advocacy for Nonprofits." In Exploring Organizations and Advocacy: Strategies and Finance. Nonprofit Advocacy and the Policy Process: A Seminar Series Volume 2, edited by E. Reid and M. Montilla, 1-8. M. D. Washington DC: The Urban Institute.

Boris, E. 1999. "Organizations in a Democracy: Varied Roles and Responsibilities." In Nonprofits \& Government: Collaboration and Conflict, edited by E. Boris and C. E. Steuerle, 31-67. Washington, DC: The Urban Institute.

Boris, E. T., and C. E. Steuerle. 2006. Nonprofit and Government: Collaboration and Conflict. Washington, D.C.: The Urban Institute Press.

Bourdeaux, C. 2008. "Integrating Performance Information into Legislative Budget Processes." Public Performance \& Management Review 31:547-569.

Brinkerhoff, J., and D. Brinkerhoff. 2002. "Government-Nonprofit Relations in Comparative Perspective: Evolution, Themes, and New Directions." Public Administration and Development 22:3-19.

Carapico, S. 2003. "Foreign Aid for Promoting Democracy in the Arab World." Middle East Journal 56:379-395.

Cavatorta, F. 2006. "Civil Society, Islamism and Democratisation: The Case of Morocco." Journal of Modern African Studies 44:203-222. 
Cavatorta, F. 2012. “Arab Spring: The Awakening of Civil Society. A General Overview.” http:// www.iemed.org/observatori-es/arees-danalisi/arxius-adjunts/anuari/med.2012/ Cavatorta_en.pdf.

Child, C., and K. Grønbjerg. 2007. “Nonprofit Advocacy Organizations: Their Characteristics and Activities." Social Science Quarterly 88:259-281.

Clark, J. 1991. Democratizing Development: The Role of Voluntary Organizations. West Hartford: Kumarian Press.

Dalrymple, J. 2004. "Developing the Concept of Professional Advocacy: An Examination of the Role of Child and Youth Advocates in England and Wales." Journal of Social Work 4:179-197.

Deane, S. 2013. The Role of Civil Society in Tunisia's Transition. London, UK: International Alert.

Diaz-Albertini, J. 1993. "Nonprofit Advocacy in Weakly Institutionalized Political Systems: The Case of NGDOs in Lima, Peru." Nonprofit and Voluntary Sector Quarterly 22:317-337.

Eulau, H., and P. D. Karps. 1977. "The Puzzle of Representation: Specifying Components of Responsiveness.” Legislative Studies Quarterly 2:233-254.

European Union. 2012. Mission de Formulation Programme d'appui à la Société Civile en Tunisie "Rapport de Diagnostic sur la Société Civile Tunisienne." http://eeas.europa.eu/ delegations/tunisia/documents/projets/rapportdiagnostic_stecivile_mars2012_fr.pdf.

Ezell, M. 2006. Advocacy in the Human Services. Belmont: Lightning Source Inc.

Fenno, R. F., Jr. 1978. House Style: House Members in Their Districts. Boston: Little Brown and Company.

Guo, C., and Z. Zhang. 2014. "Understanding Nonprofit Advocacy in Non-Western Settings: A Framework and Empirical Evidence from Singapore." Voluntas: International Journal of Voluntary and Nonprofit Organizations 25:1151-1174.

Herrold, C. E. 2016. "NGO Policy in Pre- and Post-Mubarak Egypt: Effects on NGOs' Roles in Democracy Promotion." Nonprofit Policy Forum 7:189-212.

Hopkins, B. 1992. Charity, Advocacy and the Law: How Nonprofit Organizations Can Use Charitable Dollars to Affect Public Policy - Lawfully. New York: John Wiley and Sons, Inc.

Hudson, A. 2002. "Advocacy by UK-Based Development NGOs." Nonprofit and Voluntary Sector Quarterly 31:402-418.

Human Rights Watch. 2005. World Report. Accessed August 10, 2016. https://www.hrw.org/ legacy/wr2k5/.

Jewel, M. E. 1983. "Legislator-Constituency Relations and the Representative Process." Legislative Studies Quarterly 8:303-337.

Jewell, M., and M. Whicker. 1994. Legislative Leadership in the American States. Ann Arbor: The University of Michigan Press.

Khrouz, D. 2008. “A Dynamic Civil Society.” Journal of Democracy 19:42-49.

Kimberlin, S. E. 2010. "Advocacy by Nonprofits: Roles and Practices of Core Advocacy Organizations and Direct Service Agencies." Journal of Policy Practice 9:164-182.

Kingdon, J. W. 1989. Congressmen's Voting Decisions. Ann Arbor: The University of Michigan Press.

Kubba, L. 2000. “Arabs and Democracy: The Awakening of Civil Society.” Journal of Democracy 11:84-90.

Kumar, L. 1997. State and Nonprofit Sector in India: Reluctant Partners or Willing Collaborators?. Swansea: University of Wales.

Langohr, V. 2004. "Too Much Civil Society, Too Little Politics: Egypt and Liberalizing Arab Regimes." Comparative Politics 36:181-204. 
Laws, G. 1997. "Voluntary Organizations and Advocacy: The Case of Housing for Older Americans." Nonprofit and Voluntary Sector Quarterly 26:307-335.

Mayhew, D. 1974. Congress: The Electoral Connection. New Haven: Yale University Press. McCarthy, J. D., and J. Castelli. 2002. "The Necessity for Studying Organizational Advocacy Comparatively." In Measuring the Impact of the Nonprofit Sector, edited by P. Flynn and V. Hodgkinson, 102-121. New York: Academic/Plenum Publishers.

Miller, W. E., and D. E. Stokes 1963. "Constituency Influence in Congress.” American Political Science Review 57:45-56.

Mosley, J. 2010. "Organizational Resources and Environmental Incentives: Understanding the Policy Advocacy Involvement of Human Service Nonprofits." Social Service Review 84:57-76.

Najam, A. 2000. "The Four-C's of Third Sector-Government Relations: Cooperation, Confrontation, Complementarity, and Co-Option." Nonprofit Management \& Leadership 10:375-396.

Neal, T. 1996. Lawmaking and the Legislative Process: Committees, Connections, and Compromises. Arizona: Oryx Press.

Pfeffer, J., and G. Salancik. 1978. The External Control of Organizations: A Resource Dependency Perspective. New York: Harper \& Row.

Pitkin, H. F. 1967. The Concept of Representation. Berkeley: University of California Press.

Pollard, A., and J. Court. 2005. "How Civil Society Organisations Use Evidence to Influence Policy Processes: A Literature Review.” Working Paper 249. London: Overseas Development Institute.

Raudla, R. 2012. "The Use of Performance Information in Budgetary Decision-Making by Legislators: Is Estonia Any Different." Public Administration 90:1000-1015.

Reid, E. 1999. "Advocacy and the Challenges It Presents for Nonprofits." In Nonprofits \& Government: Collaboration and Conflict, edited by E. Boris and C. E. Steuerle, 31-67. Washington, DC: The Urban Institute.

Reid, E. J. 2000. Structuring the Inquiry into Advocacy. Washington, D.C.: The Urban Institute.

Richardson, L. E., Jr., and P. K. Freeman. 1995. "Gender Differences in Constituency Service among State Legislators.” Political Research Quarterly 48:169-179.

Rojas, 0. 1999. "The Role of Civil Society in Sustainable Development." In Civil Society at the Millennium, edited by K. Naidoo, 69-84. West Hartford, Connecticut: Kumarian Press.

Romzek, B., and J. A. Utter. 1997. "Congressional Legisaltive Staff: Political Professionals or Clerks." American Journal of Political Science 41:1251-1279.

Rosenthal, A. 1986. "The Consequence of Constituency Service." Journal of State Government 59:25.

Rosenthal, A. 1996. "State Legislative Development: Observations from Three Perspectives." Legislative Studies Quarterly 21:169-198.

Sabatier, P., and D. Whiteman. 1985. "Legislative Decision Making and Substantive Policy Information: Models of Information Flow." Legislative Studies Quarterly 10:395-421.

Saidel, J. 2002. "Nonprofit Organizations, Political Engagement, and Public Policy." In Exploring Organizations and Advocacy, edited by E. Reid and M. Montilla, 1-18. Washington DC: The Urban Institute.

Salamon, L. 1999. “Government-Nonprofit Relations in International Perspective." In Nonprofits \& Government: Collaboration and Conflict, edited by E. Boris and C. E. Steuerle, 31-67. Washington, DC: The Urban Institute.

Salamon, L. 2002. The Tools of Government. New York: Oxford University Press. 
Schmid, H., M. Bar, and R. Nirel. 2008. "Advocacy Activities in Nonprofit Human Service Organizations: Implications for Policy.” Nonprofit and Voluntary Sector Quarterly 37:581-602. Smillie, I. 1999. "At Sea in a Sieve?." In Stakeholders: Government-NGO Partnerships for International Development, edited by I. Smillie and H. Helmich. London: Earthscan Publications.

Smith, R. A. 1984. "Advocacy Interpretation, and Influence in the U.S. Congress." American Political Science Review 78:44-63.

Squire, P. 1993. "Professionalism and Public Opinion in State Legislatures." Journal of Politics 55:479-491.

Stepan, A. 2012. "Tunisia's Transition and the Twin Tolerations." Journal of Democracy 23:89-103.

Suleiman, I., and K. Henderson. 2007. "Comparative Report on the Stae of the Parlaiment in Egypt, Jordan, Lebanon, and Morocco." United Nations Development Programme. www. ifes.org/sites/default/files/parcomp418.pdf.

Uphoff, N., and A. Krishna. 2004. "Civil Society and Public Sector Institutions: More than a Zero-Sum Relationship." Public Administration and Development 24:357-372.

Wright, J. R. 1990. "Contributions, Lobbying, and Committee Voting in the U.S. House of Representatives." American Political Science Review 84:417-438.

Yom, S. 2005. "Civil Society and Democratization in the Arab World." Middle East Review Affairs 9:14-33.

Young, D. 1999. "Complementary, Supplementary, or Adversarial? A Theoretical and Historical Examination of Nonprofit-Government Relations in the United States." In Nonprofits and Government: Collaboration and Conflict, edited by E. T. Boris and C. E. Steuerle. Washington, D.C.: Urban Institute Press.

Young, D. 2000. "Alternative Models of Government-Nonprofit Sector Relations: Theoretical and International Perspectives." Nonprofit and Voluntary Sector Quarterly 29:149-172.

Young, D. 2010. “A Journal of Nonprofit Policy.” Nonprofit Policy Forum 1(1):1.

Supplemental Material: The online version of this article offers supplementary material (DOI:npf-2016-0027). 